\title{
Selected Reference Works, 2007-08
}

\author{
Sarah Witte and Mary Cargill
}

This article follows the pattern set by the semiannual series initiated by the late Constance M. Winchell more than fifty years ago and continued first by Eugene Sheehy and then by Eileen Mcllvaine. Because the purpose of the list is to present a selection of recent scholarly and general works, it does not pretend to be either well balanced or comprehensive. A brief roundup of new editions of standard works is provided at the end of the articles. Code numbers (such as AC527) have been used to refer to titles in the Guide to Reference Books, 11th ed. (Chicago: ALA, 1996).

\section{Folk Literature}

Haase, Donald. The Greenwood Encyclopedia of Folktales and Fairy Tales. Westport, Conn.: Greenwood Press, 2007. 3 vols. \$389.95 (ISBN 9780313334412). LC 2007-031698. E-book: Greenwood, $\$ 329.95$.

This three-volume encyclopedia represents yet another valuable contribution by this publisher to the field of folklore and folk culture studies. In particular, it complements the outstanding Greenwood Encyclopedia of World Folklore and Folklife, edited by William M. Clements (Westport: Greenwood Press, 2006), reviewed in an earlier issue of this column. The encyclopedia under review here focuses its attention on the fascinating, broad, but sometimes difficult-to-define domain of the folk, fairy, and fantasy tale. As the articles in this work clearly and convincing demonstrate, while drawing its origins from ancient widespread oral tradition, it extends as well into far more consciously crafted work, whether that be the constructed collections produced by the great documenters and compilers of the 19th and early 20th centuries or more full-blown literary renderings and adaptations of these narratives or original works consciously modeled on their style, including much of the work in the fields of fantasy and much science-fiction literature. In an age when the original oral milieu has shrunken drastically in importance, media renderings and children's literature also have taken on an enhanced role in continuing these traditions, while children's oral culture, "urban legend," and some other areas of less formal discourse serve as a continuation of slightly diminished source material.

The subject material surveyed here is of potential interest to a broad range of disciplines-history, literature, anthropology, psychology, sociology, religion, and the arts. The motifs, themes, and images addressed by this literature have long been a

\footnotetext{
Sarah Witte and Mary Cargill are reference librarians in Butler Library at Columbia University; e-mail: spurgin@columbia.edu and cargill@columbia.edu. Although it appears under a byline, this list is a project of the Columbia University Libraries and notes are signed with the initials of one of the following staff members: Barbara Sykes-Austin, Avery Library; Seth Kasten, Burke Library; James Coen, Business and Economics Library; Karen Green, Helen Lane, Robert H. Scott, and Junko Stuveras, Butler Library; and Breck Witte, Library Information Technology Office.
} 
source of fascination, and their study can provide fascinating insights into human culture and psychology, both collective and individual.

In approximately 650 essays, ranging from one to several pages in length, an international team of academic specialists masterfully documents, in a clear, informative, and thought-provoking manner the key aspects of this wide-ranging field. Included here are: substantive essays on the major genres (folk tale, fairy tale, legend, joke, myth, children's literature, urban legend, magical realism, film and video, etc.); on key concepts for research and analysis such as motif, variant, contamination; on the traditions of individual regional, linguistic, or national traditions; on major scholars such as Aarne, Thomson, or Jung; on collectors and compilers like Grimm and Afanasiev; on literary reshapers of these tales such as Anderson, Kay Nielsen; on major character types, including kings, mothers, ogres, thieves, and witches; on classic story types such as Snow White or Sleeping Beauty; on modern producers of fantasy literature like Garcia Marquez and Tolkien; on key relevant topics such as sex and sexuality, trauma and therapy, feminism, violence, or colonialism; on classic collections such as the Arabian Nights, the Kalevala, or Gesta Romanorum; on illustrators, musicians, and key media producers; and finally, on selected modern authors and adaptations influenced by this type of literature. Few items in the latter group are likely to be found by readers coming to this encyclopedia to look them up; rather, they are clearly intended to serve as serendipitous discoveries by a reader browsing the work.

And, indeed, the style and content of the volume as well as a variety of internal links greatly encourage such exploration. Cross-references to other articles in the encyclopedia are indicated by boldface in the text. Ample use is also made of the various motif-indexing systems available for this area of study, and a brief section at the beginning of the volume does a good job of describing the character of each of them. Individual articles end with a bibliography of key works, supplemented by a much longer bibliography at the end of the volume. The bibliographic listings could have been more extensive, however. In more than one of the articles read by this reviewer, passing reference was made to important compilations or works that were not provided with precise citations anywhere in either of the lists of literature. An index at the end provides more access to the contents.

The availability of this title in Greenwood's digital collection provides even more powerful access to this rich resource. Given the publisher's successful track record in this area, one hopes that Greenwood is also going to take a shot at bringing the various motif-index system into truly usable shape online. These indexes, linking classification systems to collections of stories, seem ideally suited for Web presentation; and yet, curiously, no truly satisfying and comprehensive approach seems to have been undertaken by anyone to date.

This is clearly one of the outstanding reference titles to appear in the last two years. It is probably in a great number of reference collections already and deserves to be included in virtually any college, university, public, or school library collection.-R.H.S.

\section{Religion}

The Holiness-Pentecostal Movement: A Comprehensive Guide. Ed. Charles Edwin Jones. Lanham, Md.: Scarecrow Press; Chicago: American Theological Library Association, 2008. (ATLA bibliography series.) 500p. $\$ 95$ (ISBN 9780810860933). LC 2007-50885.

In 1974, the American Theological Library Association began to publish its bibliography series; the first volume in that series was A Guide to the Study of the Holiness Movement, by Charles Edwin Jones. Jones has now produced a revised and expanded work of the same name, but with four volumes instead of one covering 
three of the broad Holiness movements: the Wesleyan Holiness Movement (two volumes, 2005); the Keswick Movement, centered in Great Britain (2007); and the Holiness-Pentecostal Movement.

Millions of Americans belong to denominations (e.g., the Church of the Nazarene, the Salvation Army, the Wesleyan Methodist Church) that ultimately descend from the National Association for the Promotion of Holiness, itself coming mainly out of the Methodist tradition. Also important in the rich and complex history of the Holiness Movement were the camp meeting tradition, openness to the ministry of women, ecumenical interaction among Christians of various denominations, and, early in the Pentecostal strand of the Holiness Movement, interracial assemblies such as the seminal Azusa Street Revival in Los Angeles. Most significant were theological and spiritual principles such as perfection, sanctification, and baptism with the Holy Ghost. Many persons who converted at camp meetings had later slipped back to their worldly ways; some Holiness evangelists believed that the new principles of perfectionism strengthened the convert so that he or she could resist temptations to backslide. Those who embraced the principal of "entire sanctification" and emphasized the importance of the gift of the Holy Spirit to the early church on the Day of Pentecost left their mainline denominations to become the first members of the Pentecostal Movement. After experiments with speaking in tongues, the HolinessPentecostal Movement experienced a split, with the speaking-in-tongues groups becoming the modern Pentecostal Movement (not included within the four volumes); Jones' Holiness-Pentecostal bibliography concerns the denominations that developed and remained within the Holiness tradition. Although the Holiness-Pentecostal Movement does not include the huge Assemblies of God and other Pentecostal groups, it does include such major denominations as the Church of God (Cleveland, Tennessee) and the
Church of God in Christ, as well as more than a hundred smaller bodies.

Jones' extensive bibliography is surely the most comprehensive reference book on the Holiness-Pentecostal Movement. Most of the book consists of a section arranged by Holiness-Pentecostal bodies, large and small. Following are sections on schools within the tradition and on biography. Citations are generally not annotated, but the annotations accompanying the names of bodies are invaluable for identifying and distinguishing them $-\mathrm{a}$ valuable feature in itself. Some citations include a library location, and those in the biography section usually have the person's occupation and their birth and death locations and dates. The comprehensive index will be much appreciated by reference librarians and other users.

Researchers interested specifically in African-American Holiness and/or Pentecostal bodies will still find Jones' 1987 Black Holiness: A Guide to the Study of Black Participation in Wesleyan Perfectionist and Glossolalic Pentecostal Movements convenient to use, despite its earlier date of publication and some overlap with his 2008 volume. (The index in the new volume contains some 200 citation numbers under "African Americans" without further subject breakdown.) Do not discard that volume if your collection already includes it. More important is that all of Jones' most recent bibliographies (except perhaps the Keswick volume) are needed for serious study of the history and contemporary state of American religion and its representation overseas, whether we have some familiarity with this tradition or not.-S.K.

\section{Jewish Studies}

Roth, Norman. Dictionary of Iberian Jewish and Converso Authors. Madrid: Aben Ezra Ediciones; Salamanca: Universidad Pontifica de Salamanca, 2007. 765p. €50 (ISBN 978-84-88324-29-0). LC 2008-381704.

This bibliography represents a major contribution to the study of medieval 
Iberian and Jewish studies and won the 2007 Judaica Bibliography Award from the Association of Jewish Libraries. It includes 434 individual writers and more than 100 anonymous works, and it aims to "locate as much as possible all published examples of the writings, in whatever language, of Jews in Spain and Portugal, from the earliest times to the expulsion of 1492." (Introd.)

Entries are arranged alphabetically by the author's family name, when available, or by first name; variant or incorrect forms are cross-referenced, with notes on attribution. The names of converts (conversos), whether to Islam or Christianity, are marked with an asterisk. Entries include biographical details, including place(s) of residence, followed by a short list of important secondary literature on the author. These are followed by a list of works, listing all editions, and citations to translations and partial translations. Hebrew titles are not transliterated, though Arabic titles are. Critical or otherwise important editions are bulleted, and angle brackets indicate an edition of holograph manuscripts.

Anonymous works are gathered at the beginning of the book and arranged by topics including works on the Talmud, Literature, Quabbalah, and Philosophical works; as well as Bibles written or printed by Jews in Spain, Passover Haggadot, and liturgical works. Geographical coverage extends into Provence, where Quabbalah developed in the 12th century, for the time it was part of the kingdom of AragonCatalonia.

The Dictionary of Iberian Jewish and Coverso Authors is the result of ongoing research begun in 1973, when the author, now Professor Emeritus of Jewish History at the University of Wisconsin, was a graduate student. Professor Roth's intervening publications include Maimonides: Essays and Texts (1985); Jews, Visigoths, and Muslims in Medieval Spain (1994); Conversos, Inquisition, and the Expulsion of Jewish from Spain (1995); Medieval Jewish Civilization: An Encyclopedia (editor, 2002);
Medieval Iberia: An Encyclopedia (co-editor, 2003); Daily Life of the Jews in the Middle Ages (2005); and numerous articles.

Although published in Spain, the text is in English and includes an introductory essay by the author, a bibliography of "important references and works cited in the text," and indexes by topic and place. It is recommended for all libraries supporting research in Iberian studies and Jewish studies. It may be hard to find; both YBP and Amazon list it as being out of print, and WorldCat only lists 38 owning libraries; but it is listed on the publisher's Web site, and it is definitely worth having to support graduate-level research. - S.W.

\section{Fine Arts}

Oweis, Fayeq S. Encyclopedia of Arab American Artists. Westport, Conn.: Greenwood Press, 2008 (Artists of the American Mosaic). 306p. $\$ 85$ (ISBN: 0-313-33730-6; ISBN-13: 978-0-31333730-7). LC: 2007-039798. E-book: Greenwood, \$93.50.

This is the third title in the "Artists of the American Mosaic" series, presenting biographies of 85 Arab American artists of the 20th and 21st centuries. The book seeks to "provide a window into the lives of Arab Americans in general and the lives and contributions of Arab American visual artists in particular, with the aim of educating the readers about issues and challenges facing people of Arab heritage." (Introd.) This heritage is defined as having derived from one or more of the 22 Arab countries that make up the Arab League and includes first-, second-, and third-generation American-born artists of Arab descent as well as immigrants whose early experience and training were gained in the Arab world.

As with the volumes on Asian American and Jewish American artists, the Encyclopedia is presented in an A to $\mathrm{Z}$ arrangement of names, with each biographical entry extending to three or four pages with a brief bibliography and a list of selected public collections 
in which the artist's work can be found. Black-and-white portraits of the artists and their work are provided for most of the entries. Visual media include painting, sculpture, calligraphy, ceramics, mosaics, textiles, videography, photography, conceptual art, digitized forms, and installation works.

Consistent with other titles in the series, there are an additional eight pages of color illustrations in a separate section in the center of the volume. A list of resources on Arab American artists and Arab culture in the United States is a useful entrée to organizations, museums, cultural and community centers, workshops, and other nonprofit institutions involved in access to and promotion of the Arab American artistic and cultural community. A selected bibliography of books, periodical articles, reports, exhibition catalogues, and dissertations published between 1985 and 2004 is followed by a materials index, under which media and form, and their associated artists, are listed (examples include airbrush, collage, digital art, Islamic art, mosaics, murals, silkscreen). An index of names and subjects completes the volume.-B.S.-A.

\section{The Grove Encyclopedia of Materials and}

Techniques in Art. Ed. Gerald W.R.

Ward. New York: Oxford University

Press, 2008. 828p. $\$ 150$ (ISBN 978-019-531391-8). LC: 2008-002486.

This is the latest compilation derived from Grove Art Online to bring together selected entries from the database on specifically defined subjects. (Earlier volumes, published since 2000, have included American art before 1914, Italian renaissance and mannerist art, decorative arts, and classical art and architecture; since 2006 they have also been published simultaneously as e-books. All have been noted in this column.)

This volume moves away from the earlier arrangements of style and period, geography and genre, to materials and techniques, with the result that "the modern, artificial distinction between the so-called fine arts and the so-called crafts is not recognized." (Introd.) Mastery of the material is the subject here; consequently, coverage includes, in addition to the techniques of painting and sculpture, those required of glasswork, metalwork, ceramics, textiles, woodwork, concrete, plastics, leather, feather, ivory, horn, shell, and other animal-derived products, works on paper, photography, holography, video art, and more. Bookbinding, beadwork, japanning, and rustication processes are described and illustrated, as are the analytical methods required for conservation and restoration of materials, technical evaluation methods, and artists' techniques such as "pouncing" (526-28).

Illustrations are not numerous throughout the text, where they appear in black and white. Sixteen color plates are collected between pages 414 and 415 . As with all the previous volumes, the entries are essay-length, scholarly but accessible to the novice reader or student, and fully cited bibliographically. The contributors are listed in a separate section; there is a list of abbreviations for geographical names, weights and measures, other terms, and a general index. This will be a convenient and much-used reference work, whether consulted in print or online, for students and practitioners in any branch of conservation and preservation work; for artists, craftspeople, builders, architects, and restorers; and for anyone interested in the properties of materials used in the making of works of art. - B.S.-A.

\section{Sociology}

Encyclopedia of Race and Racism. Ed. John Hartwell Moore. Detroit: Macmillan Reference USA/Thompson Gale, 2008. 3 vols. \$345 (ISBN 9780028660202). LC 2007-024359. E-book: Gale, call for pricing.

As any librarian who works with undergraduates knows, there is nothing like being able to show students a single, reliable source with which they can begin a research project. This is especially true if, as is often the case, a student has cho- 
sen a topic that might daunt a seasoned scholar with its complexity, or conversely, is at an utter loss for what to research in a given area. Indeed, it seems that the editors at Macmillan were seeking a "one stop" resource when they approached John Hartwell Moore with the project that became the Encyclopedia of Race and Racism. The result is a three-volume reference work that examines issues related to the distinct concepts of race and racism, provides access to further resources, and creates an ontological framework for this difficult subject matter.

In response to the breadth of issues covered by the encyclopedia, Moore and his fellow editors created a Thematic Outline, which they hope will aid users in finding articles of interest, as well as prompt interest in articles that "may not have been the object of a search." This themed outline of twenty-eight categories can be found in volume one after the list of contributors. Signed articles - on topics as divergent as the Genetics and Athletic Performance and Mayan Genocide in Guatemala - are arranged in alphabetical order throughout the encyclopedia, each containing bibliographies and "see also" references. Volume three also contains the text of thirty primary sources (some as excerpts), a sizable annotated filmography, and an index to the entire work.

The Encyclopedia of Race and Racism has a broader geographical perspective than the Greenwood's 2005 Encyclopedia of Racism in the United States and a larger scope than the single volume Encyclopedia of Race and Ethnic Studies from Routledge, although it overlaps in coverage with both. This encyclopedia belongs in any library serving college undergraduates, high school students, and their teachers. The subject matter, while vast, aligns nicely with the sorts of assignments and topics one encounters as a reference librarian serving students. It is easy to imagine it being used to hone research topics and locate further resources, as well as to build lesson plans and syllabi.-H.L.
The SAGE Dictionary of Sports Studies.

Ed. Dominic Malcolm. London: Sage

Publications, 2008. 290p. \$99.95 (ISBN

978-1-4129-0734-7). LC 2007-922934.

"Sports studies is an emerging discipline, and thus much of the clarification, definition and consolidation that other subjects take for granted still needs to be achieved." This statement in the introduction to The Sage Dictionary of Sports Studies describes both why such a work is needed as well as the challenges it faces. This work treats sports studies as the study of the social aspects of sport, though it emphasizes the importance of this field by frequent reference to the growing economic impact that sports and leisure activities have attained.

Entries are concise (generally a page or so in length), and well written; each includes a short bibliography of one or more key works pertaining to the entry. The integration of the bibliography into the text in this manner makes this reference work easier to use than it might be if its bibliography were separate from the text. Cross-references are also integrated into the text but are supplemented by a good index.

Scholarly entries, here taken from the " $\mathrm{B}$ " entries, address the anthropological (Balinese cock-fighting, Barmy Army, Bedoin syndrome); economic (boycotts, broadcasting rights, broken-time payments); historical/biographical (David Beckham, George Best, Jack Broughton); legal (Bowman ruling); psychological (burnout); philosophical (Baudrillard, binaries); physical (blood-doping, Body); political; and tactical (bodyline) aspects of sports, as well as addressing seminal works in sports studies (Beyond a Boundary, and Barbarians, Gentlemen, and Players).

American readers will no doubt observe a marked U.K. emphasis and focus. This focus is reflected in the work's contributors ( 5 from the United States and 28 from the United Kingdom/Ireland/Australia/Canada), the entries (three times as many reference cricket as do baseball), 
and the length of the entries ("David Beckham" covers more than twice the space as does "Tiger Woods").

Overall, this is a well-structured and well thought-out work; and, while future editions might benefit from a more balanced geographic focus, this is a valuable contribution to the fledgling field of sports studies reference works.-B.W.

\section{Business and Economics}

The Definitive Guide to CDOs: Market, Application, Valuation, and Hedging.

Ed. Gunter Meissner. London: Risk Books, 2008. 638p. \$205 (ISBN 9781906348014).

The thirty-four contributors to this volume represent a wide spectrum of professionals and academics, many of whom are both. Of the six sections into which the book is divided, the longest is the third, with nine chapters, covering the topic of $\mathrm{CDO}$ valuation approaches. As the introduction points out, the content level of some chapters can be understood by a nonprofessional; but, to understand the content of certain areas, such as the third section, a knowledge of stochastic processes, algebra, and calculus is necessary. This is emphasized by the reminder that, as CDOs are complex financial structures, they require the modeling and correlation of 125 or more credit curves.

In all this is a comprehensive presentation of every aspect of CDO markets, application, valuation, hedging, regulation, and model validation. Each chapter is concluded with a relevant bibliography, and the volume contains a detailed index. Recommended for any library serving finance professionals or graduate and above academic business libraries. -J.C.

\section{History and Area Studies}

Medieval Travel Writing. Adam Matthew

Digital (www.amdigital.co.uk/collections/Medieval-Travel-Writing/Default.aspx). Price varies.

Is it possible to write anything these days without thinking about its connection to the current global economic crisis? Perhaps-but in this case you'll have to look elsewhere. The trend toward globalization has shrunk the world and vividly demonstrates our interconnectedness and commonality. It's not unusual to think of this as a recent phenomenon, but for centuries wanderers, scholars, and warriors have been traversing the globe and commenting on neighbors near and far, celebrating both differences and similarities. It may be that these early efforts to shrink the world to a comprehensible size have informed the rash of medieval/early modern travel courses that are currently being taught in institutions from Columbia University to the University of Leeds to Hong Kong University-yet another sign of global commonality.

Aiding immeasurably in making such courses possible is the recently introduced database from Adam Matthew Digital, Medieval Travel Writing. As Kim Phillips, professor of history at the University of Auckland and the collection's editor, points out in the introductory essay that greets the database's users, these works were among the most important and popular in circulation in the Middle Ages, and the writings are of interest to "historians, literary scholars, anthropologists, geographers and representatives of many other disciplines." While almost all the works are available in printed editions, many of these editions are old and unavailable to the widest range of scholars.

The texts in question are from manuscripts in a number of libraries, from the large and prominent (the British Library, the Bibliothèque Nationale de France, Yale University's Beinecke Library, the Österreichische Nationalbibliothek) to the smaller and prominent (Durham Cathedral Library; Trinity College, Dublin) to the smaller and less prominent (Chetham's Library, Manchester; the Herbert, Coventry History Centre), with a total of 26 participating libraries in all.

There are over 120 manuscripts included, in high-resolution, zoomable digital images. The works, which range 
from the 13th to the 16th centuries, are in a variety of languages - Latin, French, German, Spanish, and others - and in a variety of hands. Expected authors like Marco Polo and John Mandeville are joined by lesser-known lights such as Ruy Gonzalez de Clavijo or Ricoldo de Montecroce. Each record offers the option of downloading the entire document or individual folios as PDFs, which can be used in teaching and research. In addition, the records offer links to secondary literature on the text, available in PDF form. A knowledge of palaeography is crucial to appreciate the primary source material, which will limit the audience for this central portion of the database, but a knowledgeable instructor will be able to choose material to engage the attention of untrained students.

Advanced search functions allow sophisticated keyword searching, using Boolean operators, truncation, and proximity. Results for manuscripts point to the cataloging information, not the content, as it would not have been feasible to transcribe each of these manuscripts. Results in the secondary material allow the choice of display in the PDF image or in a highlighted transcript of the content. Search help is available and is quite extensive, using numerous screenshots.

The database consciously adds value to the texts themselves. The site also includes original essays by David Abulafia of Gonville and Caius College, Cambridge, writing on the medieval Mediterranean world; Peter Jackson of the University of Keele, writing on medieval travel in Asia; Andrew Jotischky of Lancaster University, writing on medieval geographical knowledge; Kim Phillips again, writing on medieval travel on Far Asia; and Alison Stones, of the University of Pittsburgh, writing on the pilgrimages to the Holy Land. In this way, the database combines primary source material with secondary literature for complete and complex exposure to the topic. The database also has a section called "Further Resources," which includes a plethora of material to round out the experience of medieval travel. A slideshow features nearly 100 images of atlas pages, route maps, manuscript illuminations and other images that illustrate everything from trade routes to a royal Tartar feast. Not all the images are described, however, and the reader is left to determine on his or her own what the significance is of an illumination from BL MS Royal 19 D 1, which shows a man and woman embracing in bed while a griffon howls outside their window (the text below it mentions King Philippe, but there seems little connection).

Another feature in the additional resources is a timeline of Conquest, Exploration, Prominent Figures, and Religion \& Politics. The reader can choose up to two of these categories, horizontally bracketing a timeline with a moving cursor; in this way, looking simultaneously at, say, Exploration and Conquest, one sees that, in the span of 1176 to 1185 , Pethahiah of Regensburg traveled to Baghdad and Gerald of Wales' Topographia hiberniae followed Henry II's conquests in Ireland (Exploration) at the same time as Manuel I was defeated by Seljuks, Jerusalem surrendered to Saladin, and the Third Crusade was launched (Conquest).

A third feature is an extensive bibliography but one that, it appears, is not searchable. It is true that, as mentioned above, a given manuscript record includes secondary bibliography, but not always the bibliography that also appears in the Featured Resources list. For example, Jacques Le Goff's The Medieval Imagination appears in the bibliography, but a search on "Goff" in the simple search box takes the reader to the record for BL MS Harley 3099. This manuscript contains the notorious letter of Prester John, and the highlighting points to the full cataloging information, which includes mention of “Goff I181, ISTC ii00181000," but without pointing readers to an explanation of this citation, should the Incunabula Short Title Catalogue not be familiar to them. Whether The Medieval Imagination appears as sec- 
ondary literature in a specific record is a question to be answered by someone with far more time on his or her hands than this writer.

The final featured resource is a collection of links to a variety of sites, from digital manuscript collections such the American Digital Scriptorium or the Czech Manuscriptorium or the German Manuscripta Mediaevalia Handschriftendatenbank, to relevant journals such as Scriptorium or Studies in Travel Writing, and institutes such as the Sorbonne's Centre de Recherche sur la Littérature des Voyages and the Centre for Travel Writing Studies at Nottingham Trent University.

All in all, this is an extremely welcome addition to the resources currently available for the study of the medieval world. Its secondary material forms an attractive lure to lead students to the higher level of study necessary to appreciate its primary sources.-K.L.G.

\section{Bracewell, Wendy, and Alex Drace-}

Francis. A Bibliography of East European Travel Writing on Europe. Budapest; New York: Central European University Press, 2008. (East Looks West, vol. 3). 584p. $\$ 55$ (ISBN 9639776122). LC 2007-052344.

While contemporary developments serve to emphasize the common cultural and historical heritage of Europe, it is worth remembering that one consistent feature of that common identity has been a fairly enduring division of the region along eastern and western lines, the result of differing commonalities of ethnic and linguistic composition, confessional influences, economic conditions, and historical experience. Those long-term differences were deepened in the modern period by an economic and political constellation in which (at the risk of oversimplification) a relatively more industrialized, national, constitutional, parliamentary West confronted an economically more backward, agrarian, imperial, autocratic, anti-national East, and even more by the post-World War II regime pitting a capitalist West against a Communist East. Throughout, natural and political obstacles often served as barriers to regular communication and routine contact. For both sides, the opposite was a mysterious "other" of peculiarly familiar character, offering unexpected variations on familiar themes. Depending on the era and the beholder, that "other" might be the object of admiration or of contempt, an ideological rival or a model for emulation, a menacing threat or a potential source of liberation, a promising commercial partner or a source (or object) of economic exploitation. These attitudes found expression on many levels, from official policy to public opinion. A particularly rich source for documenting these materials is the writing of travelers from one part of the continent to the other. Their accounts, describing a somewhat exotic world to their readers, can provide fascinating insights both into the attitudes they brought to their observation, but also to aspects of the visited society not clearly documented in local sources. Certainly, Western travel accounts have long been an important source for the study of East European history.

As the editors of this volume note, far less systematic work has been done on Eastern European accounts of the West. This volume represents a important step toward addressing that problem. It is one volume in a larger study entitled East Looks West, issued by Central European University press, so typical of the pathbreaking work that that publisher does for East European studies. The other two volumes, Under Eastern Eyes (2008) and Orientations (not yet published) provide, or will provide, respectively, a series of essays on East European travel writing and an anthology of writing drawn from them.

As might be expected for a first attempt at a survey, the volume leaves some areas uncovered. For reasons of time and workload, only book titles are represented here. Nor is all of "Eastern Europe" included. Russia is not treated 
here, perhaps because of the vast amount of additional effort that would have been required, but a consideration of its travel literature seems essential to any comprehensive treatment of the "East confronts West" question in a European context. Also absent from consideration are Belarus, the Baltic nations, and Finland. The period covered is limited for the most part to materials produced between 1550 and 2000.

The editors of this volume, Wendy Bracewell and Alex Drace-Francis, are scholars specializing in the South Slavic, Czech, and Romanian affairs. The team of compilers they supervise are simply identified as "scholars familiar with the appropriate national/linguistic tradition." Individual chapters are devoted to nativelanguage following linguistic/cultural traditions: Albanian; Bosnian, Croatian, and Serbian; Bulgarian; Czech; Greek; Hebrew and Yiddish; Hungarian; Macedonian; Polish; Romanian; Slovak; Slovene; and Ukrainian. These are followed by an additional chapter on writing in "languages of international circulation" (Latin, German, and so on), as well as a chapter containing an auxiliary bibliography on travel accounts of Europe. Each chapter begins with a short essay describing the kinds of scholarly literature and bibliographic resources dealing with the travel literature of each of these groups.

The bibliographies themselves begin with a list of anthologies (and in the Polish case, at least, a list of some secondary literature). The remainder is divided into chronological categories, usually 1550 1700, 1700-1850, 1815-1918, 1918-1945, 1945-1989, and 1989-2000, with fewer subdivisions where the total number of titles is much smaller. Each entry contains a full bibliographic citation, along with a translation of the title into English. In many cases, dates of birth and date are given, along with a very brief indication of the individual's occupation or role. The extent of the latter coverage varies greatly from section to section and is often very spotty, and the professional characteriza- tions are frequently so formalistic as to be of little use. In the Polish list, at least, this reviewer found a number of prominent individuals (including Jaroslaw Iwaszkiewicz, Mieczyslaw Jastrun, Jozef Ignacy Kraszewski, Tadeusz Konwicki) who were given dates of birth but no professional characterization and others (for example, Stefan Kisielewski and Jan Dantyszek) whose characterizations, while formally correct, fail to do justice at all to their most prominent roles in Polish history and society. Each entry also helpfully indicates what countries are treated in the account.

Where appropriate, there are crossreferences within each section to entries for authors located in other sections, but they would have been far more helpful had they pointed to the bibliography number rather than the section in which they were included. Indexes of places visited and of translations (arranged by language) provide additional access to the contents.

It is useful to have this collocation of sources for a hitherto understudied area, and every library providing serious coverage of East European studies and many libraries dealing with European studies in general will want to acquire this title. It needs to be remembered as well that this is but a section of a much larger work, a supplement as much as a freestanding title. That said, it must still be noted that this work falls disappointing short of the demands on current printed bibliography. In an age where one can go to WorldCat, limit by language, date, and the subject keywords description and travel, and come up with a large list of publications, one wants much more from printed bibliography than simply a list of authors and titles. The real value, of course, is the process by which these items were selected as potentially interesting. Since the majority of them were in fact examined by the compilers, it seems unfortunate that a brief annotation simply reflecting the reasons that an item seemed worthy of inclusion would have been 
helpful. That examination could surely have been used to provide more robust author information as well. Pains were taken to identify the regions discussed, and that is useful value added. One only wishes that the project had gone a little further in its description. - R.H.S.

\section{The Welsh Academy Encyclopaedia of}

Wales. Ed. John Davies, Nigel Jenkins, Menna Baines, and Peredur I. Lynch. Cardiff: University of Wales Press, 2008. 1059p. ill. £55 (ISBN 9780708319536; 070831953X). LC 2008-399906.

Wales has been the subject of far fewer encyclopedias than England or Scotland. Two multivolume encyclopedias on Wales were published in the 19th century: the 10-volume Welsh Encyclopaedia (1854-79) and the two-volume Wales: Historical, Topographical and Biographical (1871-75). Indeed, the preface states that this is "the first-ever single volume encyclopaedia in the history of Wales." It was compiled by the Welsh Academy (founded in 1958), which has previously undertaken the English-Welsh Dictionary (1995) and the Oxford Companion to the Literature of Wales (1986).

This represents the work of some 400 contributors and a team of four co-editors. Entries are classified in three main categories: people, places, and other topics. Thirty-six subject categories cover such themes as agriculture, music, visual culture, transportation, food and drink. Articles are arranged alphabetically by topic and are enhanced by color photographs (place names), black and white portraits (biographical entries), line maps, and facsimiles of publications. Most entries are short and concise, ranging from one-sixth to one-half page. Some topics, such as the "Historiography of Wales," occupy a bit more space, spreading over three columns. The importance of coal industry is reflected in the six-page article on "Coal and coal mining," and "Geology" also occupies about seven pages; likewise, eight pages are devoted to "Music," which covers traditional Welsh music to jazz. There is an index of names and topics. Articles are not signed and do not include bibliographical notes. For further reading, the editors recommend consulting the Wales volume of the World Bibliographical Series or online catalogs, such as the catalog of the National Library of Wales.

Recommended for all types of libraries to update their collection of reference books on Wales. - J.S.

\section{Encyclopedia of the Cold War: A Politi- cal, Social, and Military History. Ed.} Spencer C. Tucker. Santa Barbara, Calif.: ABC-CLIO, 2008. 5 vols. ill., maps. $\$ 495$ (ISBN 9781851097012); Ebook, \$620 (ISBN 9781851097067). LC 2007-009681.

This encyclopedia consists of five volumes, each about the size of a volume of the Encyclopaedia Britannica. A general index and a set of maps are repeated in each volume. Volume 1 starts with three general essays: "The Cold War, a personal perspective" (3-10), "Origins of the Cold War to 1950" (11-17), and "Course of the Cold War (1950-1991)" (19-31). Main articles are arranged alphabetically in the first four volumes. Each article is signed and followed by a short bibliography and cross-references. They are often illustrated with monochromatic portraits or photographs, and some includes maps as well. Volume 4 also contains Appendices: "Rank structures, selected Cold War militaries" (a multilingual comparative chart) and "Cold War chronology" (1945-1991), a Glossary, a Selected bibliography (151723), and a List of editors and international contributors (some missing institutional affiliations). Volume 5 is devoted to a collection of documents. Each document is preceded by an introduction, and the source of the text is indicated at the end. The documents are drawn from Englishlanguage, printed sources such as U.S. government documents, Department of State Bulletins, congressional documents, presidential papers, foreign broadcast information services, newspapers, and 


\section{ROUTLEDGE reterence}

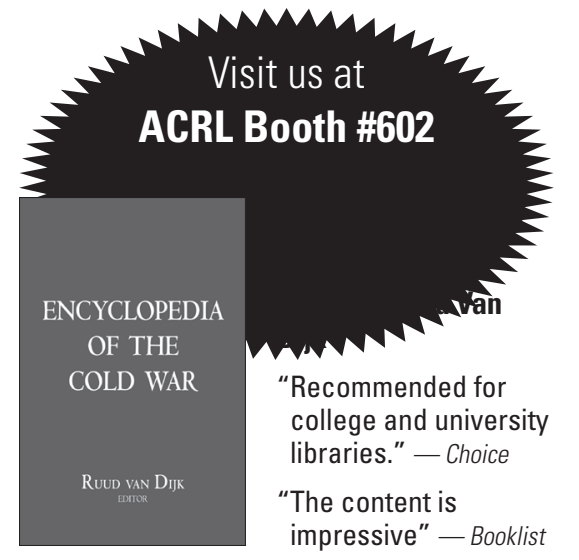

HB 978-0-415-97515-5 • May $2008 \bullet \$ 550$

\section{Also New from Europa Publications}

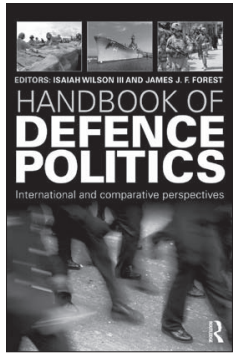

\section{Handbook of Defence Politics: International and Comparative Perspectives \\ Edited by Isaiah Wilson III and James J.F. Forest}

HB 978-1-85743-443-9 • February 2009 • \$295

Combining analytically detailed essays with statistics, a glossary, and comprehensive bibliography, this title is a unique one-stop reference source as well as a training and education guide on the politics of defence worldwide.

For more information on these and other Routledge Reference products, please visit www.routledge.com/reference or call 1.800.634.7064

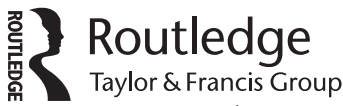

I iness

journals. It is not clear how much material has been drawn from recently opened foreign archives, although there are a number of foreign scholars among the contributors.

It is a commendable effort to place the Cold War in the context of global social, political, and military history. The links are, however, not always effectively presented. The encyclopedia includes too many general geographical and biographical articles that are readily available in the Statesman's Yearbook, national biographical dictionaries, and other standard reference resources. It could have focused more on the Cold War as the dominant theme of the era. It falls between the history of the cold war and a general social and political history of the world between 1945 and 1991.

Recommended only for school libraries and small public libraries that may not have easy access to government documents and general reference collections. - J.S.

Encyclopedia of the Cold War. Ed. Ruud van Dijk et al. New York: Routledge, 2008. 2 vols. $\$ 495$ (ISBN 9780415975155; 0415975158). LC 2007-039661.

This encyclopedia on the Cold War is better focused on the Cold War itself without neglecting the social, political, and military context of the war. The first volume contains a list of contributors, an alphabetical list of all the entries, and a thematic list of entries, while the preface explains the purpose and methodology. The introduction presents a concise history of the Cold War divided into four eras, followed by the entries A-J and a 57-page index to the set. Volume 2 has the entries $\mathrm{K}-\mathrm{Z}$ and repeats the set index. The index is analytical, extensive, and useful.

The 424 individual articles were contributed by 191 scholars, and the encyclopedia emphasizes multiarchival research, including Eastern European resources, an expanded geographic scope, and the role of ideologies as one component in civilizations. 
Articles are signed and accompanied by a bibliography, a "Further Reading" section, which typically includes half a dozen or more titles, and "see also" references to people, institutions, and ideas. There are no maps or illustrations. It is more focused on the Cold War, and it is better edited than the Tucker encyclopedia. Take, for example, the entry on the National Security Council, which traces its origin, evolution, and the role of the national security advisor in the formation of American foreign policy very clearly and concisely in a little over two pages. The Tucker encyclopedia does not include the National Security Council as a separate entry. Nationalism is another example: while the van Dijk article focuses on the difference in U.S. and Soviet views of nationalism and the dissolution of the Soviet Union in face of nationalism, the Tucker article tries to cover the entire world including South Asia, Latin America, and the Middle East, thus obscuring the significance of nationalism in the Cold War. A comparison of articles in both encyclopedias on cultural and social topics such as "Music" further demonstrates the more focused approach of the van Dijk encyclopedia. Recommended for college and university libraries. - J.S.

\section{Documents on British Policy Overseas: Diplomacy in the Twentieth Cen-} tury [electronic resource]. Ann Arbor, Mich.: Proquest. http://dbpo.chadwyck.com/home.do. Price varies.

This is an amalgamation of three major print compilations of documents on British foreign policy prepared over a number of years by the British government: British Documents on the Origins of the War, 1898-1914; Documents on British Foreign Policy, 1918-1939; and Documents on British Policy Overseas 1946-. Therefore, information relating to the conduct of both world wars are not included, a fact that could be more prominently stressed. It also does not include the material in British Documents on Foreign Affairs published by the University Publications of
America, which were selected from the Foreign Office Confidential Prints.

The material included consists of unpublished archival material, letters, memos, reports, and other written materials, which were not designed to be read individually, in a vacuum. These come from a bewildering series of government departments, familiar to scholars by their abbreviations (such as FO, CO, CAB). Proquest has designed the interface to stress simplicity, but it has oversimplified the material to the point of near-uselessness.

A series of documents on foreign policy must have an intellectual and chronological coherence, either in the original arrangement or in the indexing, which the print volumes have. The default search screen for the Proquest version is a keyword search, which can turn up a massive amount of unrelated items. There is also a document heading search, with no explanation of what this means. There is an author search, with a link to a list of names. This list was apparently computer-generated, with no intellectual enhancements, so the student will find entries for, for example, A.E., Italian Minister, Chamberlain, Mr. (with no hint as to which of the three important Chamberlains this might be). The same problem exists for the search by Recipient: "The Prime Minister," "Truman, President," as well as "President Truman," are all possibilities. There is also a somewhat confusing "Place of Origin," which includes addresses such as "1 Cornhill, London," "The War Office," and so on.

Presumably, most users will just do a keyword search, which is also problematic. "Boer War" finds fifty entries, some of which just mention the war in passing. But "South African War" turns up 105 entries, most from chapter VII "The South African War" in Volume One of British Documents on the Origins of the War, 1898-1914. There is no link between the two terms; real subject indexing is expensive, but absolutely crucial when searching for historical events when the 
terminology varies. The basic search may work for the student who is told just to find one or two "primary sources" to attach to a bibliography, but it is too vague to help real scholars.

It is also possible to browse the collections, and the default browse is by date. Again, this may help the student who just needs a document to cite, but the most useful way to browse is by collection, mentioned in a sidebar. This will eventually take the reader to the text of the print volumes, including the detailed explanatory prefaces and the useful subject and author indexes. Unfortunately, there is no easy way to get from the listings in the index to the actual documents, and it is too bad that Proquest didn't build on the scholarship of the original volumes.-M.C.

\section{New Editions, Supplements, etc.}

The third edition of the Concise Oxford Dictionary of Literary Terms (1st ed. New York: Oxford Univ. Pr, 1990. BE73) has been published as the Oxford Dictionary of Literary Terms (New York: Oxford Univ. Pr., 2008). This guide to "hard words alphabetically arranged and briefly explained" (Pref.) has been expanded and updated, and adds about 180 new terms. The MLA Style Manual and Guide to Scholarly Publishing is also in its third edition (New York: MLA, 2008; 1st ed. titled simply MLA Style Manual, New York: MLA, 1985. AA317). This companion to the familiar MLA Handbook (AG2) is designed for graduate students and scholars, and includes "protocols for submitting manuscripts to publishers" (Pref.) as well as a discussion of legal issues relating to publishing and suggestions for formatting dissertations and theses.

Keeping up with theory has been simplified with the second edition of Cultural Theory: The Key Concepts (London: Routledge, 2008; 1st ed. 1999), which has added new entries on technology, genetics, and cyber culture as well as new categories including education, sports, and leisure. Some articles have brief bibliographies, and there is a longer bibliography at the end, arranged, unfortunately by author, not by subject, so its usefulness is limited.

The second edition of the Cambridge Guide to American Theatre (Cambridge: Cambridge Univ. Pr., 2007; 1st ed. 1993) has revisions and updates through 2006. William Smith's frequently reprinted classic Dictionary of Greek and Roman Antiquities (London: J. Murray, 1896-99) has been reissued under the title $A$ Dictionary of Greek and Roman Culture (London: Tauris, 2008), which might lead some to think it is a different book.

The industrious Adrian Room has revised and enlarged African Placenames: Origins and Meanings of the Names for Natural Features, Towns, Cities, Provinces, and Countries (Jefferson, N.C.: McFarland, 2008; 1st ed. 1994). This now lists more than 2,500 names and includes some useful appendixes, listing official languages, official names, independence dates, and an interesting list of names with Biblical connections. Hans Zell has also prepared the third edition of Publishing, Books, and Reading in Sub-Saharan Africa: A Critical Bibliography (London: Hans Zell, 2008; 1st ed. titled Publishing and Book Development in Africa: A Bibliography. Paris: Unesco, 1984). It now includes some 2,500 annotated entries, most of which were published between 1996 and 2007, so the older editions are still useful. There is now a greater emphasis on "the relative significance of the material included, thus offering a more critical dimension in reviewing the available literature on the subject" (Pref.).

The second edition of the Columbia Gazetteer of the World (New York: Columbia Univ. Pr., 2008; 1st ed. 1998; published originally in 1952 at the Columbia Lippincott Gazetteer of the World. CL85) adds some 7,000 new entries. Martin Gilbert has prepared the fourth edition of the Routledge Historical Atlas of Jerusalem (London: Routledge, 2008; 1st ed. titled Jerusalem, Illustrated History Atlas, London: M. Gilbert, 1977). This has expanded coverage of recent growth and an updated bibliography. 
The second edition of the New Palgrave Dictionary of Economics (New York: Palgrave Macmillan, 2008; 1st ed. entitled The New Palgrave: a Dictionary of Economics, New York: Macmillan, 1987, CH52, which was a revision of the 1910 classic, The Dictionary of Political Economy) is an extensive revision, now in eight volumes rather than four. This new edition "has shed much of its historical character: from providing a record of development of economic thought, it has become more of a snapshot of contemporary economics" (Pref.). (Ponzi scheme is discussed under Post-Keynesian economics.) Fortunately for reference librarians, there is still some historical material; "Capitalism" does discuss Adam Smith, and there are plenty of entries on dead economists. Unfortunately, though, the new index does not give page or volume numbers for the entries, just references to the titles of articles, a surprising and disappointing development.

Another major reference work, The Encyclopedia of Latin American History and Culture has also appeared in a second edition (Detroit: Gale, 2008; 1st ed. New York: Scribner's, 1996). There are more than 500 new entries, and some 400 have been revised and updated. Coverage of the lands of the non-Spanish speaking Caribbean has been added, and more Spanish and Portuguese sources have been included. There are eight new "mega essays," on topics such as democracy, economic development, race, and ethnicity. Las Vanguardias Literarias en Bolivia, Ecuador, Colombia, Peru y Venezuela: Bibliografia y Antologia Critica (Madrid: Iberoamericana, 2008) is the title of the second, revised edition of the 1999 Las Vanguardias Literarias en Bolivia, Colombia, Ecuador, Peru: Bibliografia y Antologia Critica, which was published as volume two of the series Bibliografia y Antologia Critica das Vanguardas Literarias no Mundo Iberico e Luso-Brasileiro.

The Library Company of Philadelphia has published a second, expanded version of Afro-Americana, 1553-1906: A Catalog of the Holdings of the Library Company of Philadelphia and the Historical Society of Pennsylvania (New Castle, Del.: Oak Knoll Pr., 2008; 1st ed. Boston: G.K. Hall, 1973) which adds some 2,500 books, pamphlets, and broadsides. These new entries are added as a supplement to the original bibliography and arranged alphabetically, with no subject index. The original subject index in the 1st edition remains, with its confusing arrangement; it is too bad that it wasn't redone.

The Encyclopedia of World's Fairs and Expositions (Jefferson, N.C.: McFarland, 2008 ) is a revised and updated version of the Historical Dictionary of World's Fairs and Expositions, 1851-1988 (New York: Greenwood, 1990) and now discusses fairs through the proposed 2010 fair in Shanghai. The work has also added a detailed guide to Internet resources, including general sources, and Web sites devoted to individual fairs.

The second edition of the Encyclopedia of the History of Science, Technology, and Medicine in Non-Western Cultures (Berlin: Springer, 2008; 1st ed. 1997) has updated and added many new entries, and rewritten the ones in the first edition that "did not always eliminate the anti-Eurocentric language and occasionally allowed a polemical tone to come through. In the new edition, we move from advocacy to analysis." (Pref.)

A number of important supplements and continuations have been published. The long-awaited African American $\mathrm{Na}$ tional Biography edited by Henry Louis Gates and Evelyn Brooks Higginbotham (New York: Oxford Univ. Pr., 2008) is technically a supplement to Oxford's 1999 American National Biography and replaces the 2004 Oxford publication African American Lives. The 4,100 entries are arranged alphabetically and include, unlike other national biographies, living people. It is also available online as part of the Oxford African American Studies Center. Volume III of the second edition of The Heads of Religious Houses: England and Wales, covering the years 1377-1540, 
was published in 2008. Kelly DeVries has published a 2003-2006 update of his Cumulative Bibliography of Medieval Military History and Technology, which adds to but does not supersede his 2004 update. Volume 2 of A Comprehensive, Annotated Bibliography on Mahatma Gandhi, issued by Greenwood Press as no. 55 of its Bibliographies and Indexes in World History, entitled Books and Pamphlets about Mahatma Gandhi, was published in 2007. It attempts to list "all books and pamphlets published in the English language" on Gandhi's influence, as well as biographies and compilations of Gandhi's writings published after 1995.

A cumulated index to volumes 1-29 of the Biographisch-bibliographisches Kirch- enlexikon was published in 2008. This monumental work can also be searched for free at www.bautz.de/bbkl/. The fifth and final volume of the third edition of The Encyclopedia of Christianity, originally published in German as Evangelisches Kirchenlexicon, was published in 2008. The two-volume index to Johannes Hoops' second edition of the Reallexikon der Germanischen Altertumskunde, which began publishing in 1973, completes the set. And finally the Annuaire Statistique de la France, published since 1878, announced that, as of 2008, it will only appear online. It is available for free at www.insee.fr/fr/ppp/publications/asf. htm.-M.C.

\section{Available NOW!}

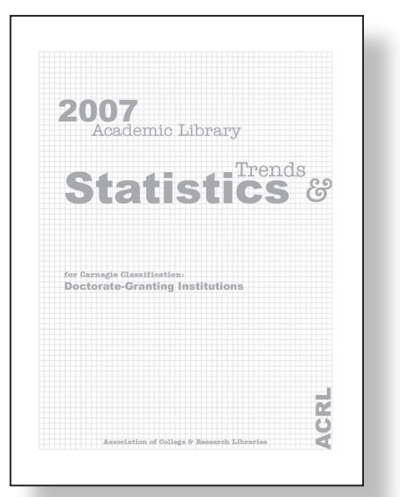

\section{ACRL 2007 Academic Library Trends and Statistics}

The Center for Informatics Research in Science and Scholarship, University of Illinois, compiler

Introducing the latest in a series of annual publications that describe the collections, staffing, expenditures, and service activities of academic libraries in all Carnegie classifications. It includes data from 1,311 academic libraries in five major categories. The three-volume set includes Associate of Arts institutions, Master's Colleges and Universities/ Baccalaureate Colleges, and Research/Doctoral-granting Institutions. The individual print volumes for Associates Colleges, Masters/Baccalaureate, and Doctoral-Granting institutions are also available for purchase. There is also an online edition that provides electronic access to the data for each institution. See http://acrl.telusys.net/trendstat/2007/index.html. For more information about the ACRL Academic Library Trends \& Statistics, please contact Mary Jane Petrowski at mpetrowski@ala.org or at 800-545-2433, x2523.

\section{Available in print through the ALA Online Store at: http://www.alastore.ala.org}




\section{BEST PRACTICE}

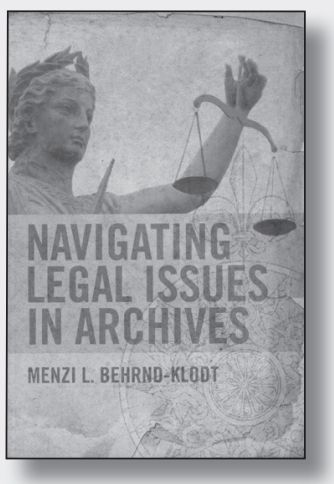

Navigating Legal Issues in Archives

Menzi Behrnd-Klodt

Society of American Archivists (August 2008)

340 pp., Soft cover

Product Code: BOOKSAA-0530

\$69.95 (SAA member price: \$49.95)

Archival Internships: A Guide for Faculty, Supervisors, and Students Jeannette A. Bastian and Donna Webber Society of American Archivists (March 2008)

I26 Pp., Soft cover

Product Code: BOOKSAA-053I $\$ \mathbf{2 9 . 9 5}$ (SAA member price: \$24.95)

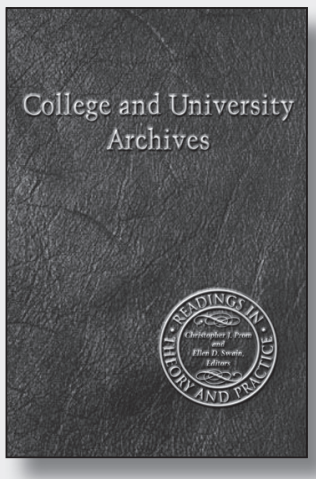

Campus Case Studies are reports by university archivists on working solutions for born-digital records. Check out these free resources at www.archivists.org/publications/epubs/

College and University Archives: Readings in Theory and Practice Edited by Christopher Prom and Ellen Swain Society of American Archivists (June 2008) 360 pp., Soft cover Product Code: BOOKSAA-0532 \$54.95 (SAA member price: \$39.95)

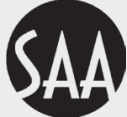

SOCIETY OF American Archivists
To order books or browse archives titles, www.archivists.org/catalog

\section{CAMPUS} CASE STUDIES

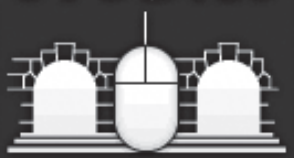

